\title{
What if communities held the solutions for universal health coverage?
}

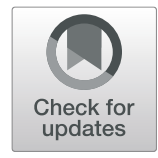

John C. Reeder ${ }^{1 *}$ (D, Marie-Paule Kieny ${ }^{2}$, Rosanna Peeling ${ }^{3}$ and François Bonnici ${ }^{4}$

\begin{abstract}
This commentary highlights the value of community-engaged social innovations to advance health care delivery in low- and middle-income countries and to accelerate universal health coverage. It emphasizes the importance of research to guide the innovators on what works, what does not work to make their innovations sustainable and to replicate and scale them up as relevant. It also helps to demonstrate impact and to enhance uptake within the health systems.
\end{abstract}

Keywords: Social innovation, Health care delivery, Community engagement, Multidisciplinary research

\section{Multilingual abstracts}

Please see Additional file 1 for translations of the abstract into the five official working languages of the United Nations.

\section{Background}

Universal health coverage is one of the most pressing objectives of the World Health Organization (WHO). A billion people worldwide lack access to basic health care services, even when proven treatments exist. To extend health care and services to the most remote regions and marginalized populations, we must actively engage people and communities as the principal actors in their own health.

\section{Main text}

Social innovation is a powerful process for this. Examples of this are diverse, and include nurse-run primary healthcare posts in rural Rwanda [1], community-led human immunodeficiency virus (HIV) testing centres in China [2], and drug shop integrated care programme in Uganda [3]. However, an essential element of innovation is that not every idea works. It is important to be bold and try new ideas, but even more important to be objective about improving or dropping them. We need to collect and analyse information about why these projects

\footnotetext{
*Correspondence: reederj@who.int

${ }^{1}$ Special Programme for Research and Training in Tropical Diseases (TDR),

World Health Organization, Geneva, Switzerland

Full list of author information is available at the end of the article
}

do or do not work, and to determine whether the social innovations can be scaled up, sustained and applied in different settings.

Quality research, that is reliable, ethical and answers the key questions, is necessary to make policy decisions. For this to occur, research cannot be conducted on community members as subjects; rather, research must be undertaken with community members as co-investigators. Capacity for this to occur needs to be developed to allow community members who are implementing innovations to be research generators, and for them to be able to partner with researchers in equitable collaborations.

In 2014 a collaborative undertaking emerged between the Special Programme for Research and Training in Tropical Diseases (TDR), the University of Cape Town, the University of Oxford and the London School of Hygiene and Tropical Medicine [4, 5]. The Social Innovation in Health Initiative, SIHI, was developed on the premise that solutions to many health problems can emerge from communities in low-resource settings. The initiative is dedicated to advancing the understanding and application of social innovation in the global South to address inequities in health. It has expanded in 2016 to include social innovation research hubs in China, Colombia, Malawi, Uganda and the Philippines. The country hubs provide a platform to convene the various health system actors and promote and catalyse social innovations in health through research, capacity building and advocacy. To date (July 2019), 40 social innovations in 17 countries have been showcased and studied $[5,6]$. 
Businesses, governments, donors and civil society organizations are working together to improve healthcare access for the poor. The initiative has been developing research capacity and tools to assess whether and how these innovations strengthen health systems and reduce inequity. New global partners have joined the initiative, including the Ahimsa Fund, the Fondation Merieux, the Joint United Nations Programme on HIV/AIDS (UNAIDS), the United Nation University and the World Health Organization.

\section{Conclusion}

What if people were given the opportunity to address their own health problems with locally generated solutions? What if these solutions were sustainable and scalable? What if improving healthcare also empowered people, provided economic benefit, and provided hope? Surely, this is a worthwhile topic for research, demonstrated in the thematic series on social innovation to transform health care delivery.

\section{Additional file}

Additional file 1: Multilingual abstracts in the five official working languages of the United Nations. (PDF $344 \mathrm{~kb}$ )

\section{Abbreviations}

HIV: Human immunodeficiency virus; TDR: Special Programme for Research and Training in Tropical Diseases, cosponsored by the United Nations Children's Fund, the United Nations development Programme, the World Bank and the World Health Organization; UNAIDS: The Joint United Nations Programme on HIV/AIDS

\section{Acknowledgements}

Pamela Hartigan passed away on 12 August 2016. Her leadership in exploring how best to advance social business in health and extend this to the broader concept of social innovation, continues to inspire us today. Beatrice Halpaap has provided input and helped to coordinate the development and submission of this commentary. We also acknowledge the many people who have contributed to move the Social Innovation in Health Initiative forward.

\section{Authors' contributions}

JCR, MPK, RP and FB contributed to the promotion of social innovations in order to accelerate universal health coverage and to the establishment of the Social Innovation in Health Initiative. MPK acted in her capacity as Assistant Director General of the Health Systems and Innovation Cluster at the World Health Organization in Geneva, Switzerland until 2017. FB acted in his capacity of Founder and Director, Bertha Centre for Social Innovation and Entrepreneurship until 2018 and serves as a Board member of the Centre. JCR wrote the first draft of the commentary and all authors provided input. All authors read and approved the final manuscript.

\section{Authors' information}

'Director, Special Programme for Research and Training in Tropical Diseases (TDR), World Health Organization, Geneva, Switzerland.

${ }^{2}$ Director of Research, French National Institute of Health and Medical Research INSERM, Paris, France.

${ }^{3}$ Professor and Chair of Diagnostic Research, London School of Hygiene and Tropical Medicine, London, UK.

${ }^{4}$ Board member, Bertha Centre for Social innovation and Entrepreneurship, University of Cape Town, Cape Town, South Africa and Head, Schwab Foundation for Social Entrepreneurship at the World Economic Forum, Geneva, Switzerland.

\section{Funding}

The Social Innovation in Health Initiative received financial support from TDR, the Special Programme for Research and Training in Tropical Diseases co-sponsored by UNICEF, UNDP, the World Bank and WHO. TDR is able to conduct its work thanks to the commitment and support from a variety of funders. These include our long-term core contributors from national governments and international institutions, as well as designated funding for specific projects within our current priorities. For the full list of TDR donors, please visit our website at: https://www. who.int/tdr/about/funding/en/ . Additional funding targeted to the Social Innovation in Health Initiative have been provided by Sida, the Swedish International Development Cooperation Agency.

\section{Availability of data and materials}

Not applicable.

Ethics approval and consent to participate

Not applicable.

\section{Consent for publication}

Not applicable.

\section{Competing interests}

Each author declares no conflict of interest in communicating the content of this manuscript. TDR has funded part of the work of the Social Innovation in Health Initiative and the Bertha Centre has received funds from TDR in this context.

\section{Author details}

'Special Programme for Research and Training in Tropical Diseases (TDR), World Health Organization, Geneva, Switzerland. ${ }^{2}$ French National Institute of Health and Medical Research, Inserm (Institut national de la santé et de la recherche médicale), Paris, France. ${ }^{3}$ London School of Hygiene and Tropical Medicine, London, UK. ${ }^{4}$ Bertha Centre for Social innovation and entrepreneurship, University of Cape Town, Cape Town, South Africa.

Received: 12 June 2019 Accepted: 7 August 2019

Published online: 05 September 2019

\section{References}

1. Social Innovation in Health Initiative. Resources, case studies. One Family Health. 2016. https://www.socialinnovationinhealth.org/downloads/ Case_Studies/One_Family_Health_SIHI_Case_Collection.pdf. Accessed 22 Mar 2019.

2. Social innovation in health initiative. Resources, case studies. Social entrepreneurship for sexual health. 2016. https://socialinnovationinhealth. org/downloads/Case_Studies/SESH_SIHI_Case_Collection.pdf. Accessed 22 Mar 2019

3. Social Innovation in Health Initiative. Resources, case studies. Drug Store Integrated Care. 2016. https://www.socialinnovationinhealth.org/downloads/ Case_Studies/Drug_Shop_Integrated_Management_of_Childhood_Illness_ SIHI_Case_Collection.pdf. Accessed on 22 Mar 2019.

4. World Health Organization. Social innovation. http://www.who.int/tdr/ research/social-innovation/en/ 2019. Accessed 22 Mar 2019.

5. Social Innovation in Health Initiative. https://socialinnovationinhealth.org/ all-innovations/ 2019. Accessed 22 Mar 2019.

6. van Niekerk L, Chater R, Naydenova E, Lim J, Chamas L, Manderson L, et al. Social innovation in health: case studies and lessons learned from low- and middle-income countries: World Health Organization; 2017. https://www. who.int/tdr/publications/year/2017/social-innovation-in-health/en/. Accessed 22 Mar 2019. 